\title{
ANGIOTENZINĄ KONVERTUOJANČIO FERMENTO INHIBITORIAUS SUKELTOS ANGIOEDEMOS GYDYMAS
}

\author{
Nora Šiupšinskienè ${ }^{1,2}$, Žygimantas Tverskis ${ }^{3}$, Sigutė Norkien $\dot{1}^{1}$ \\ ${ }^{1}$ Klaipèdos universiteto Sveikatos mokslu fakultetas, ${ }^{2}$ Lietuvos sveikatos mokslu universiteto \\ ligonine Kauno klinikos, ${ }^{3}$ Klaipédos vaiku ligoninè
}

Raktažodžiai: angioedema, angiotenziną konvertuojančio fermento inhibitoriai, farmakologija.

\begin{abstract}
Santrauka
Angiotenziną konvertuojančio fermento (AKF) inhibitorių sukelta angioedema yra pavojinga gyvybei būklè, kuri pasireiškia maždaug 0,5 proc. pacientų, vartojančių AKF inhbitorius. Nors AKF inhibitorių sukeltos angioedemos patofiziologija susijusi su padidejusiu bradikinino kiekiu kraujo plazmoje, standartinis gydymas paprastai apima kortikosteroidus ir antihistamininius medikamentus. Apžvalgos tikslas yra apibendrinti ịrodymus, pagrindžiančius farmakoterapiją, gydant AKF inhibitorių sukeltą angioedemą.
\end{abstract}

\section{Ivadas}

Angiotenziną konvertuojančio fermento (AKF) inhibitoriai yra vieni iš dažniausiai skiriamų antihipertenzinių medikamentų visame pasaulyje [1]. Šių preparatų sukelta angioedema pasireiškia maždaug 0,5 proc. pacientų, vartojančių AKF inhibitorius, tačiau statistika rodo, kad iki 30 proc. suaugusių pacientų, pristatytų ị skubiosios pagalbos skyrių

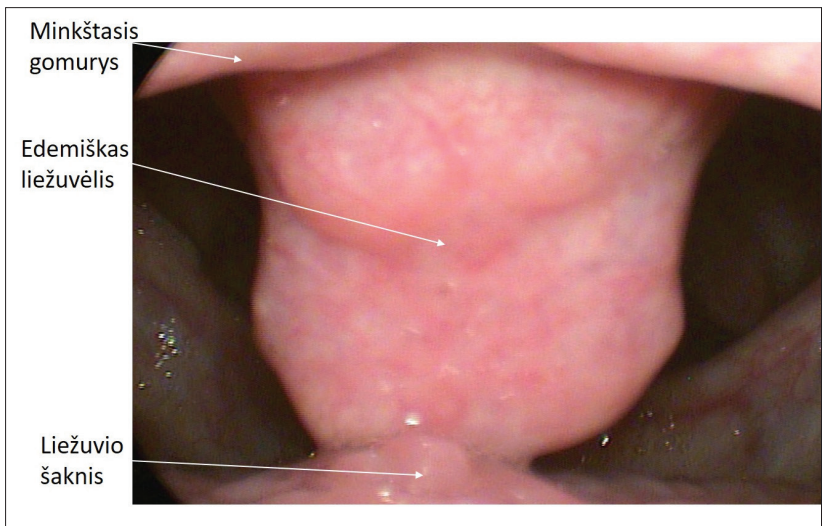

1 pav. Liežuvėlio edema, sukelta AKF inhibitorių dèl galvos ir kaklo angioedemos, būklè buvo susijusi su AKF inhibitorių vartojimu. AKF inhibitorių sukelta angioedema dažniausiai pasireiškia kaip lokalizuotas galvos ir kaklo sričių patinimas, kuris gali būti nuo švelnios lūpų, liežuvio ar liežuvèlio edemos (1 pav.) iki gyvybei pavojingos gerklu (2 pav.) ar ryklès edemos [2-4]. Šie simptomai gali atsirasti tik pradejus vartoti paskirtus AKF inhibitorius arba vartojant juos iki dešimties metų [5]. Kosulys yra dažniausiai pasitaikantis šalutinis AKF inhibitorių poveikis ir gali perspèti apie angioedemos grèsmę [6]. Manoma, kad vartojant AKF inhibitorius, bradikininas nèra suskaidomas, dèl to jo perteklius jungiasi prie bradikinino $\mathrm{B}_{2}$ receptorių, kurie yra endotelyje, o tai sukelia padidejjusị ląstelių pralaidumą ir edemą $[7,8]$. Literatūroje aprašytas AKF inhibitorių sukeltos angioedemos gydymas apima kortikosteroidus, antihistamininius vaistus, $\mathrm{H}_{2}$ receptorių blokatorius, alfa agonistus, šviežiai šaldytą plazmą, C1 inhibitoriaus koncentratą, ekalantidą (kalikreino inhibitorius) ir ikatibantą (bradikinino $\mathrm{B}_{2}$ receptorių blokatorius) [9-13]. Aptikta keletas klinikinių tyrimų, kuriuose ivertintas bet kokio AKF inhibitoriaus sukeltos angioedemos gydymo veiksmingumas ir didelè dalis gydymo skiriama neturint įrodymais pagrịstų duomenų.

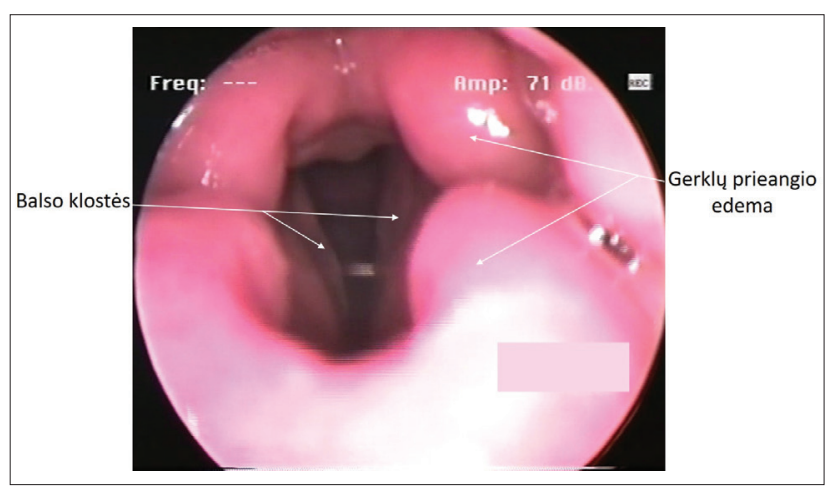

2 pav. Gerklų prieangio edema, sukelta AKF inhibitorių 
Tyrimo tikslas - sistemingai peržiūrèti paskelbtą klinikinę, įrodymais pagrịstą AKF inhibitorių sukeltos angioedemos farmakoterapiją.

\section{Tyrimo medžiaga ir metodai}

Atlikta detali literatūros apžvalga internetinèse PubMed, Ovid MEDLINE ir Embase duomenų bazèse pagal angioedemai apibrèžti tinkamus raktinius žodžius: angioedema, viršutiniai kvejpavimo takai, angiotenziną konvertuojančio fermento inhibitoriai, šalutinis poveikis, angioedemos gydymas. Straipsnyje apsiribota klinikiniais tyrimais, atsitiktinių imčių kontroliuojamaisiais tyrimais, stebejimo duomenimis. Išanalizuoti duomenys apie pacientų atranką ir įtraukimo kriterijus, kontrolę, angioedemos gydymo schemas, atsaką i gydymą, nepageidaujamą šalutinị poveikį. Straipsniai, kuriuose aprašomi paveldimos, nesteroidinių vaistų nuo uždegimo sukeltos ir alerginès angioedemos tyrimai, buvo atmesti.

\section{Rezultatai}

Pradinè duomenų bazès paieška nustatè 905 straipsnius, ịskaitant 349 iš PubMed, 293 iš Ovid MEDLINE ir 263 iš Embase duomenų bazių. Patikrinus tinkamumą ir atmetus dublikatus, 63 straipsniai buvo pateikti tolesnei recenzijai. Penkiasdešimt aštuoni straipsniai netiko kiekybinei analizei dèl nepakankamų duomenų. Iš viso buvo itraukti 5 straipsniai, skirti kokybinei analizei. Trys tyrimai buvo daugiacentriai dvigubai akli atsitiktinių imčių tyrimai. Du tyrimai buvo perspektyvieji atvejų analizės tyrimai. Tirti pacientai, kurie buvo pristatyti ị skubiosios pagalbos skyriu Vokietijoje ir JAV. Išanalizuoti penki straipsniai, iš viso 218 atvejų (1 lentelè). Visi pacientai, ịtraukti $i$ tyrimus, buvo pilnamečiai, patekę i skubiosios pagalbos skyrių įtarus galvos ir kaklo angioedemą. Jie vartojo AKF inhibitorius, o kitos angioedemos priežastys, ịskaitant alergiją ir infekciją, buvo atmestos. M. Bas ir kt. palygino ikatibantą (30 mg, poodinè injekcija) su metilprednizolonu ir klemastinu. J. Greve ir kt. lygino C1 inhibitoriaus koncentratą su metilprednizolonu ir klemastinu. Nors abu tyrimai parodè, kad šie medikamentai buvo veiksmingi gydant AKF inhibitorių sukeltą angioedemą, tačiau hipotezè nepasitvirtino dèl mažo imties dydžio.

L. Lewis ir kt. palygino įvairias ekalantido dozes su placebu, tačiau visoms grupèms buvo leista vartoti kortikosteroidus, antihistamininius vaistus, $\mathrm{H}_{2}$ receptorių blokatorius ir (arba) adrenerginius agonistus [14]. J. Bernstein ir kt. ịtraukè pacientus atsitiktinès atrankos būdu tik po to, kai jiems gydymas $\mathrm{H}_{1}$ ar $\mathrm{H}_{2}$ receptorių blokatoriais (peroraliai, i raumenis ar i veną), kortikosteroidais (per burną ar į veną) ir epinefrinu buvo neveiksmingas [15]. Tada jiems buvo paskirtas ekalantidas arba placebas. Viename straipsnyje M. Bas ir kt. aprašè statistiškai reikšmingą vaisto veiksmingumą tarp eksperimentinès ir kontrolinès grupių [16]. Šio tyrimo metu ikatibantas buvo lyginamas su kontrole metilprednizolonu (500 mg, i veną) ir klemastinu (2 mg i raumeni). Eksperimentinejje grupeje vartojant ikatibantą, angioedemos regresavimas per keturias valandas $(p=0,02)$ ir per trumpesnị laiką buvo sklandesnis, angioedema visiškai išnyko $(\mathrm{p}=0,002)$.

\section{Aptarimas}

AKF inhibitorių sukelta angioedema yra retas, bet gali būti mirtinas šalutinis vaistų poveikis. AKF inhibitoriai blokuoja angiotenzino I virsmą angiotenzinu II ir užkerta kelią bradikinino inaktyvacijai, todèl padidejja bradikinino kiekis kraujo plazmoje [17]. Bradikininas aktyvina kraujagyslių bradikinino $\mathrm{B}_{2}$ receptorius, padidina kraujagyslių pralaidumą ir sukelia angioedemą [18]. Ikatibantas yra bradikinino $\mathrm{B}_{2}$ receptorių blokatorius, jis nesumažina bradikinino serume, bet slopina jo veikimo mechanizmą. Yra duomenų, kad gydant AKF inhibitorių sukeltą angioedemą ikatibantas gali būti veiksmingas, tačiau jo taikymas

1 lentelè. Apibendrinti mokslinių tyrimų duomenys

\begin{tabular}{|c|c|c|c|c|c|}
\hline $\begin{array}{l}\text { Autoriai/ } \\
\text { metai }\end{array}$ & Šalis & Tyrimas & $\begin{array}{c}\text { Tirtas } \\
\text { medika- } \\
\text { mentas }\end{array}$ & $\begin{array}{l}\text { Irodymų } \\
\text { lygmuo }\end{array}$ & $\begin{array}{c}\text { Medikamento } \\
\text { efektyvumas }\end{array}$ \\
\hline $\begin{array}{l}\text { Bas ir kt. } \\
(2010)\end{array}$ & $\begin{array}{l}\text { Vokie- } \\
\text { tija }\end{array}$ & $\begin{array}{l}\text { Perspektyvusis } \\
\text { atvejų analizės }\end{array}$ & $\begin{array}{l}\text { Ikati- } \\
\text { bantas }\end{array}$ & $3 b$ & $\begin{array}{l}\text { Veiksmingas, } \\
\text { tačiau nepatvir- } \\
\text { tintas statistiškai }\end{array}$ \\
\hline $\begin{array}{l}\text { Levis ir } \\
\text { kt. (2015) }\end{array}$ & JAV & $\begin{array}{c}\text { Daugiacentris } \\
\text { atsitiktinių im- } \\
\text { čių dvigubai } \\
\text { aklas }\end{array}$ & $\begin{array}{l}\text { Ekalan- } \\
\text { tidas }\end{array}$ & $1 b$ & $\begin{array}{l}\text { Nèra statistiš- } \\
\text { kai reikšmingo } \\
\text { skirtumo tarp } \\
\text { medikamento ir } \\
\text { placebo }\end{array}$ \\
\hline $\begin{array}{l}\text { Bas ir kt. } \\
(2015)\end{array}$ & $\begin{array}{l}\text { Vokie- } \\
\text { tija }\end{array}$ & $\begin{array}{c}\text { Daugiacentris } \\
\text { atsitiktinių im- } \\
\text { čių dvigubai } \\
\text { aklas } \\
\end{array}$ & $\begin{array}{l}\text { Ikatiban- } \\
\text { tas }\end{array}$ & $1 b$ & $\begin{array}{l}\text { Statistiškai } \\
\text { reikšmingai } \\
\text { veiksmingas }\end{array}$ \\
\hline $\begin{array}{l}\text { Bernstein } \\
\text { ir kt. } \\
(2015)\end{array}$ & JAV & $\begin{array}{c}\text { Daugiacentris } \\
\text { atsitiktinių im- } \\
\text { čių dvigubai } \\
\text { aklas }\end{array}$ & $\begin{array}{l}\text { Ekalan- } \\
\text { tidas }\end{array}$ & $1 b$ & $\begin{array}{l}\text { Nèra statistiš- } \\
\text { kai reikšmingo } \\
\text { skirtumo tarp } \\
\text { medikamento ir } \\
\text { placebo }\end{array}$ \\
\hline $\begin{array}{l}\text { Grev ir } \\
\text { kt. (2015) }\end{array}$ & JAV & $\begin{array}{l}\text { Perspektyvusis } \\
\text { atvejų analizès }\end{array}$ & $\begin{array}{l}\mathrm{C} 1 \\
\text { inchibi- } \\
\text { toriaus } \\
\text { koncen- } \\
\text { tratas }\end{array}$ & $3 b$ & $\begin{array}{l}\text { Veiksmingas, } \\
\text { tačiau nepatvir- } \\
\text { tintas statistiškai }\end{array}$ \\
\hline
\end{tabular}


turi būti ịvertintas atsižvelgiant ị padidejjusias išlaidas ir galimą neigiamą poveikị. Kortikosteroidai ir antihistamininiai vaistai yra pigūs, palyginti su ikatibantu, jo $30 \mathrm{mg}$ dozès kaina - maždaug 10000 USD. Atliekant pradinius klinikinius tyrimus, iki 97 proc. pacientų pranešè apie ikatibanto sukeltą paraudimą injekcijos vietoje [19]. C1 esterazès inhibitoriaus koncentratas slopina bradikinino susidarymą ir neleidžia vystytis angioedemai. Viename iš aptartų tyrimų, kuriame buvo tiriamas $\mathrm{C} 1$ inhibitoriaus koncentratas, nenustatyta, kad šis vaistas būtų veiksmingesnis už kortikosteroidus ir antihistamininius medikamentus [13]. Ekalantidas yra kalikreino inhibitorius, neleidžiantis suskaidyti didelių molekulių svorio kininogeno iki bradikinino. Ši terapija neịrodè statistiškai reikšmingo AKF inhibitorių sukeltos angioedemos sumažejimo, palyginti su placebu pacientams, kurie jau buvo vartoję kortikosteroidų, antihistamininių vaistų, $\mathrm{H}_{2}$ receptorių blokatorių ir epinefrino derinį [14]. Kortikosteroidai yra stiprūs vaistai nuo uždegimo, kurie imituoja endogeninio kortizolio poveikị. Kortikosteroidų veikimo mechanizmas apima genų ekspresijos reguliavimą leukocituose ir endotelio ląstelèse, skatinant paviršiaus molekulių adhezijos pokyčius, citokinų išsiskyrimą. Tiksliau, gliukokortikoidai stiprina endotelio barjero vientisumą, didindami jungiamujų baltymų ir mažindami proteazių, skaldančių ląstelès matricą, išsiskyrimą [20]. Kortikosteroidų nauda gydant AKF inhibitorių sukeltą angiodemą greičiausiai yra susijusi su padidèjusio kraujagyslių pralaidumo mažinimo mechanizmais, tačiau trūksta tyrimų, kurie atskleistų aiškų kortikosteroidų veikimo mechanizmą gydant AKF inhibitorių skeltą angioedemą.

Šią apžvalgą riboja palyginti nedidelis atliktų tyrimų ir juose dalyvavusių pacientų skaičius. Trys iš penkių ịtrauktų tyrimų buvo atsitiktinių imčių kontroliuojami tyrimai, kurie padidina bendrą įrodymų lygị, tačiau dẻl kai kurių tyrẻjų pasirinktų metodų sunku apibendrinti rezultatus. Patiriama sunkumų vykdant aukštos kokybės tyrimus, skirtus skirtingu AKF inhibitorių sukeltos angioedemos gydymo strategiju veiksmingumui ivertinti. Nors yra kraujo tyrimų histaminerginei angioedemai diagnozuoti, serumo žymenų AKF inhibitoriu sukeltai angioedemai nenustatyta. Reikia atmesti dilgèlinę ir kitus požymius, rodančius histamino sukeltą edemą. Kuo greičiau nustatyti AKF inhibitorių sukeltą angioedemą, nutraukti ją sukèlusių medikamentų vartojimą ir valdyti kvėpavimo takus yra pagrindiné gydymo strategija. Kai ūmiai patinus viršutiniams kvépavimo takams pacientai pristatomi ị skubiosios pagalbos skyrių, histaminerginès angioneurozinès edemos gydymas dažnai inicijuojamas prieš nustatant pagrindinę patinimo etiologiją. Ne visada saugu rekomenduoti bet kokio kvẻpavimo takų patinimo stebėseną, ypač kai kortikosteroidai, antihistamininiai vaistai, $\mathrm{H}_{2}$ receptorių blokatoriai ir alfa agonistai nèra kontraindikuotini, esant angioedemai dèl bradikinino padidejjimo. Ši apžvalga pabrèžia, kad yra aukštos kokybės tyrimų poreikis ištirti vadinamosios standartinès terapijos, kurią sudaro kortikosteroidai, antihistamininiai vaistai, $\mathrm{H}_{2}$ receptorių blokatoriai ir alfa agonistai, veiksmingumą, gydant AKF inhibitorių sukeltą angioedemą. Tolesnis šios patologijos mechanizmų tyrimas gali atverti naujas gydymo galimybes.

\section{Išvados}

1. AKF inhibitorių sukeltos angioedemos gydymo efektyvumas bradikinino blokatoriais, kalikreino inhibitoriais ir $\mathrm{C} 1$ esterazès inhibitoriumi pateisina tolesni tyrimą. Nors nuolatinė jų nauda nebuvo įrodyta, tačiau vartojimas nesukèlè žalos.

2. Viename tyrime buvo ịrodytas ikatibanto veiksmingumas, gydant AKF inhibitorių sukeltą angioedemą, palyginti su kontrole.

3. Reikalingi tolesni tyrimai, norint nustatyti standartinès farmakoterapijos kortikosteroidais ir antihistamininiais vaistais veiksmingumą ir veikimo mechanizmą, gydant šią ligą.

\section{Literatūra}

1. Agostoni A, Cicardi M. Drug-induced angioedema without urticaria. Drug Saf 2001;24:599-606.

https://doi.org/10.2165/00002018-200124080-00004

2. Banerji A, Oren E, Hesterberg P, Hsu Y, Camargo CA Jr, Wong JT. Ten-year study of causes of moderate to severe angioedema seen by an inpatient allergy/immunology consult service. Allergy Asthma Proc 2008;29:88-92.

https://doi.org/10.2500/aap2008.29.3085

3. Grossman E, Messerli FH, Neutel JM. Angiotensin II receptor blockers: equal or preferred substitutes for ACE inhibitors? Arch Intern Med 2000;160:1905-1911 https://doi.org/10.1001/archinte.160.13.1905

4. Slater EE, Merrill DD, Guess HA, et al. Clinical profile of angioedema associated with angiotensin converting-enzyme inhibition. JAMA 1988;260:967-970.

https://doi.org/10.1001/jama.1988.03410070095035

5. Mahmoudpour SH, Baranova EV, Souverein PC, et al. Determinants of angiotensin-converting enzyme inhibitor (ACEI) intolerance and angioedema in the UK clinical practice research datalink. Br J Clin Pharmacol 2016;82:1647-1659.

https://doi.org/10.1111/bcp.13090

6. Hallberg P, Nagy J, Karawajczyk M, et al. Comparison of clinical factors between patients with angiotensin-converting enzyme inhibitor-induced angioedema and cough. Ann Pharmacother 2017;51:293-300.

https://doi.org/10.1177/1060028016682251

7. Morimoto T, Gandhi TK, Fiskio JM, et al. An evaluation of risk factors for adverse drug events associated with angiotensinconverting enzyme inhibitors. J Eval Clin Pract 2004;10:499-509. 
https://doi.org/10.1111/j.1365-2753.2003.00484.x

8. Bas M. The angiotensin-converting-enzyme-induced angioedema.Immunol Allergy Clin North Am 2017;37:183-200. https://doi.org/10.1016/j.iac.2016.08.011

9. Bernstein JA, Cremonesi P, Hoffmann TK, Hollingsworth J. Angioedema in the emergency department: a practical guide to differential diagnosis and management. Int J Emerg Med 2017;10(1):15.

https://doi.org/10.1186/s12245-017-0141-z

10. Chaaya G, Afridi F, Faiz A, Ashraf A, Ali M, Castiglioni A. When nothing else works: fresh frozen plasma in the treatment of progressive, refractory angiotensin-converting enzyme inhibitor-induced angioedema. Cureus 2017;9:e972.

https://doi.org/10.7759/cureus.972

11. Cicardi M, Banerji A, Bracho F, et al. Icatibant, a new bradykinin-receptor antagonist, in hereditary angioedema. N Engl J Med 2010;363:532-541.

https://doi.org/10.1056/NEJMoa0906393

12. Culley CM, DiBridge JN, Wilson GL Jr. Off-label use of agents for management of serious or life-threatening angiotensin converting enzyme inhibitor-induced angioedema. Ann Pharmacother 2016;50:47-59.

https://doi.org/10.1177/1060028015607037

13. Greve J, Bas M, Hoffmann TK, et al. Effect of C1-esteraseinhibitor in angiotensin-converting enzyme inhibitor-induced angioedema. Laryngoscope 2015;125:E198-E202. https://doi.org/10.1002/lary.25113

14. Lewis LM, Graffeo C, Crosley P, et al. Ecallantide for the acute treatment of angiotensin-converting enzyme inhibitorinduced angioedema: a multicenter, randomized, controlled trial. Ann Emerg Med 2015;65:204-213.

https://doi.org/10.1016/j.annemergmed.2014.07.014

15. Bernstein JA, Moellman JJ, Collins SP, Hart KW, Lindsell CJ. Effectiveness of ecallantide in treating angiotensin converting enzyme inhibitor-induced angioedema in the emergency department. Ann Allergy Asthma Immunol 2015;114:245-249. https://doi.org/10.1016/j.anai.2014.12.007

16. Bas M, Greve J, Stelter K, et al. A randomized trial of icatibant in ACE-inhibitor-induced angioedema. N Engl J Med $2015 ; 372: 418-425$.
https://doi.org/10.1056/NEJMoa1312524

17. Nussberger J, Cugno M, Amstutz C, Cicardi M, Pellacani A, Agostoni A. Plasma bradykinin in angio-oedema. Lancet 1998;351:1693-1697. https://doi.org/10.1016/S0140-6736(97)09137-X

18. Zuraw BL, Bernstein JA, Lang DM, et al. A focused parameter update: hereditary angioedema, acquired $\mathrm{C} 1$ inhibitor deficiency, and angiotensin-converting enzyme inhibitorassociated angioedema. J Allergy Clin Immunol 2013;131:1491-1493. https://doi.org/10.1016/j.jaci.2013.03.034

19. Zanichelli A, Maurer M, Aberer W, et al. Long-term safety of icatibant treatment of patients with angioedema in real-world clinical practice. Allergy 2017;72:994-998.

https://doi.org/10.1111/all.13103

20. Zielinska KA, Van Moortel L, Opdenakker G, De Bosscher K, Van den Steen PE. Endothelial response to glucocorticoids in inflammatory diseases. Front Immunol 2016;7:592.

https://doi.org/10.3389/fimmu.2016.00592

\section{PHARMACOTHERAPY FOR ANGIOTENSIN CONVERTING ENZYME INHIBITOR INDUCTED ANGIOEDEMA}

N. Šiupšinskienė, A. Pašvenskaitė, S. Norkienė

Keywords: angioedema, angiotensin-converting enzyme inhibitor, pharmacotherapy.

Summary

Angioedema is a potentially life-threatening complication of angiotensin-converting enzyme (ACE) inhibitor use, occurring in up to $0.5 \%$ of users. Although the pathophysiology of ACE inhibitors-induced angioedema is attributable to elevated serum bradykinin but standard management typically includes corticosteroids and antihistamines. We sought to summarize the evidence supporting pharmacotherapy for ACE inhibitors induced angioedema.

Correspondence to: norai_s@yahoo.com

Gauta 2020-11-27 